\title{
Consequences for Future Return with Earnings Management through Real Operating Activities*
}

\author{
César Medeiros Cupertino \\ Universidade Federal de Santa Catarina, Centro Socioeconômico, Departamento de Ciências Contábeis, Florianópolis, SC, Brazil \\ Antonio Lopo Marfinez \\ FUCAPE Business School, Departamento de Contabilidade, Vitória, ES, Brazil \\ Newton Carneiro Affonso da Costa Jr. \\ Universidade Federal de Santa Catarina, Centro Socioeconômico, Departamento de Economia e Relações Internacionais, Florianópolis, SC, Brazil
}

Received on 09.04.2015- Desk acceptance on 09.16.2015 - 3d version approved on 04.02.2016.

\begin{abstract}
This article analyzes earnings management through real operating activities by firms in the Brazilian capital market. This way of manipulating outcomes takes place when managers make suboptimal decisions in terms of timing and volume of operating activities. This study tests the hypothesis that firms engaged in earnings management through real operating activities might have a negative impact on future returns. Our analysis is restricted to nonfinancial firms listed on the Brazilian Securities, Commodities, and Futures Exchange (BM\&FBOVESPA) with annual data made available by the Economatica for the years from 1989 to 2012. Empirical tests involving regression on panel data and estimation of future firm returns and outcomes indicate a negative impact on return on assets (ROA) related to manipulation through real operating activities. This finding is useful for several stakeholders. It demonstrates that manipulation through real operating activities takes place in the Brazilian capital market, suggesting that earnings management extends beyond discretionary accounting choices in this country. The main contribution is demonstrating a negative relation between earnings management by using real operating activities and future returns. This finding is relevant for investors, particularly for the purposes of comparison and valuation of securities.
\end{abstract}

Keywords: earnings management, operational decisions, real operating activities, future returns. 


\section{INTRODUCTION}

This article analyzes earnings management through real operating activities, by means of data for the years from 1989 to 2012 obtained from a sample of companies listed on the Brazilian Securities, Commodities, and Futures Exchange (BM\&FBOVESPA). The term "earnings management" describes the decision made by some managers to employ accounting methods or direct operating activities in order to meet specific goals concerning the outcomes reported in financial statements. Earnings management for such purposes is classified by considering if the methods affect the accrual-based accounting process or normal operation (Enomoto, Kimura, \& Yamaguchi, 2015). The first approach is known as "accrual-based management" (ABM) and the second as "real activities management" (RAM).

Based on the existing literature, Martinez (2013, p. 5) defined earnings management as the practice of using discretionary accounting choices (in recognition and measurement), operational decisions, and/or criteria for disclosing financial statements, within the limits of accounting standards, in order to change the earnings reported, for influencing perception of the underlying economic facts.

Earnings management is a relevant subject in the academic literature (Kothari, 2001; Santos \& Paulo, 2006). Dechow, Ge and Schrand (2010) stand out by contributing to raise awareness about earnings management and how this practice negatively affects the firm. One reason for this interest lies on the fact that book profit is used for several purposes, such as contractual obligations (e.g. debt covenants), asset valuation, and executive remuneration and bonus plans (e.g. executive equity compensation). Therefore, accounting data provide relevant informational content that is useful for a wide range of stakeholders. For instance, creditors use the figures reported to assess aspects related to firms' financial health, credibility, and viability (Ge, 2010). In turn, shareholders use earnings, among other indicators, to monitor operational performance. However, conclusions on a given entity's performance may be erroneous if shareholders are unable to identify and adjust the effects of earnings management embedded in financial statements. This distortion becomes clear in future outcomes, when an entity's performance does not match forecasts.

The hypothesis underlying this study is related to the impact of RAM on organizations' future returns. In general, earnings management distorts the financial status of a given firm, it has a negative impact on the quality of accounting figures disclosed and increases information asymmetry between managers and stakeholders (Ge, 2010). When the outcome is manipulated through operational decisions, a firm deviates from its optimum business performance and long-term financial implications emerge (Gunny, 2010). Empirical evidence (Gunny, 2010; Roychowdhury, 2006; Li, 2010) shows that manipulation through RAM affects firms' cash flow and it is likely to increase volatility. Future cash flow forecasts incorporated into share price are readjusted only when investors become aware of manipulation.

Brazil suffers from disclosure issues related both to the quality of financial statements and the consistency of their publication (Lopes \& Walker, 2008). Galdi (2008) argues that powerful influence of a country's taxation rules on financial statements and weak enforcement mechanisms are among the factors that contribute to reduce the relevance of accounting figures to a low level.

In this scenario, there is a delay before investors identify the practice of earnings management through real operating activities, and within this period they fail to adjust forecasts to firm's performance. This fact, in turn, constitutes an incentive for manipulation. Whereas engaging in RAM managers may sacrifice future returns to manipulate current outcomes (Gunny, 2010), a negative relation between RAM and return on assets (ROA) is expected in subsequent periods, and this is the essence of our research hypothesis:

- There is a negative relationship between earnings management through real operating activities and the firm's future returns.

The next section consists in a literature review, covering the current state of the art and illustrating the foundations of our research hypothesis. This is followed by an explanation of the methodology and a presentation of the outcomes observed. The paper is concluded with a synthesis of knowledge.

\section{LITERATURE REVIEW}

\subsection{Real Activities Management}

RAM takes place when managers make suboptimal decisions on timing and volume of operational activities (Xu, 2008; Gunny, 2010). This practice differs from manipulation by accruals, because it involves activities related to the firm's actual business activities. It is hard for external investors to determine which decisions should be classified as optimal or suboptimal (Graham, Harvey, \& Rajgopal, 2005; Cohen, Dey, \& Lys, 2008; Ge, 2010). This fact encourages some firms to structure transactions in order to hit the desired profit target (Graham, Harvey, \& Rajgopal, 2005), since detecting manipula- 
tion through real operating activities is more difficult than detecting ABM (Zang, 2012).

As defined by Ewert and Wagenhofer (2005, p. 1102), "real earnings management changes the timing or structuring of real transactions," so "real earnings management implies that the manager deviates from an otherwise optimal plan of actions only to affect earnings, thus, imposing a real cost to the firm." In turn, Roychowdhury (2006, p. 337) provides the following concept: "Departures from normal operational practices, motivated by managers' desire to mislead at least some stakeholders into believing certain financial reporting goals have been met in the normal course of operations." A wider definition has often been used; it claims that RAM is "a purposeful action to alter reported earnings in a particular direction, which is achieved by changing the timing or structuring of an operation, investment or financing transaction" (Gunny, 2010; Zang, 2012; Joosten, 2012). RAM can be achieved by restricting operational activities, such as delaying a new project that could increase production capacity or cutting discretionary expenses, e.g. expenditure on training personnel and marketing.

Graham, Harvey and Rajgopal (2005) analyzed the main factors that influence disclosure level in financial reports. They found that executives assign great importance to profit targets, either to meet forecasts made public by analysts or maintain the current period's outcomes in line with outcomes reported for previous financial periods. The authors also claim that executives aimed to manipulate outcomes through operational decisions even when aware that the procedure reduces the firm's financial value, relying on the belief that they might gain credibility by hitting outcome targets. This view is proposed by Burgstahler and Dichev (1997), who claim that firms gain prestige from several stakeholders - creditors, suppliers, customers, among others - when they report expectations of future growth. Graham, Harvey and Rajgopal (2005) add that executives are more keen to employ RAM if the sacrifice involved is not too big, i.e. the benefits outweigh the costs. Authors such as Demski (2004) and Ewert and Wagenhofer (2005) point out that RAM is chosen when the costs for implementing it are low when considering the risks associated with manipulation by accruals.

Zang (2012) claims that the risk of detection is lower by using RAM than ABM, since manipulation through RAM is not covered by the limits set out by the generally accepted accounting principles (GAAP) (Barton \& Simko, 2002). For instance, if management resorts to RAM by cutting research and development costs, this measure is not subject to scrutiny by regulating agencies or auditors. Additionally, reversal of accruals brings restrictions to accounting flexibility, i.e. indiscriminate use of discretionary accruals is easily detected.

Although RAM offers some advantages when compared to manipulation by accruals, it has certain restrictions, too. RAM has a direct impact on cash flow and, as a result, it is more expensive from a financial perspective. Ge (2010) noticed how RAM masks current financial performance, destroys feasible long-term competitive advantages, and potentially reduces the firm's financial value. Thus, outcomes that have been manipulated through RAM are unreliable measures distorting the quality of profits and they increase asymmetry between managers and external stakeholders. Zang (2012) argues it is unlikely that managers restrict themselves to use RAM for manipulation.

The studies conducted in Brazil seem to be incipient regarding ABM models. Despite the pertinent criticism by Paulo (2007), most scholars have not used rather refined models to estimate discretionary accruals, instead they stick with the modified Jones and KS models, except for efforts to adjust by performance or sector and analysis of panel data. The same trend may be observed in the international literature, because since 2005 it has converged to models aimed at earnings management by operational decisions.

Although this subject still needs further discussion in the Brazilian literature, some recent doctoral theses address earnings management by operational decisions. Machado (2012) studied the relation of earnings management with executive compensation. In turn, Cupertino (2013) focused on, among other issues, investors' perception of the effects of this manipulation type, as well as the relation between earnings management strategies and their determining costs and the impact on firms' future performance. It is also worth mentioning Almeida-Santos, Verhagem and Bezerra (2011) and Rey (2011), who incorporated operational decisions into their earnings management models.

Cupertino (2013) observed that the adoption of the International Financial Reporting Standards (IFRS) in Brazil triggered a shift from earnings management by discretionary accruals to manipulation by operational decisions. In short, there was an increase in earnings management by operational choices and a decrease in management by accruals.

Reis, Cunha and Ribeiro (2014) showed that, among the main management practices by real operating decisions, the companies listed on the IBrX did not use volume of sales and production levels to increase or decrease book outcomes. Moreover, manipulation of accounting accruals may have been preferred over operational decisions, since it is usually not reflected on cash flows and does not influence the firms' operational structure.

\subsection{Evidence on the Consequences of RAM}

There is still a small body of evidence on earnings management through real operating activities, particularly when compared to the findings of studies that have investigated manipulation by accruals. Managers' preferences for practices that do not affect future cash flow (Xu, 2008) may have contributed to the focus on manipulation by accruals in academic research. Never- 
theless, when firms face barriers to manage earnings by accruals, it is more likely that manipulation is achieved through real operating activities. For instance, Ewert and Wagenhofer (2005) found that the more rigid the accounting rules, the greater the barriers preventing firms from manipulating outcomes by accruals. In turn, this restriction induces managers to resort to real operating activities in order to manipulate outcomes, despite the greater financial costs involved (Oswald \& Zarowin, 2007). Consequently, earnings management is not reduced in the presence of stricter accounting standards, rather only the modus operandi changes.

Regardless of the method chosen to deal with earnings management - accruals or operational decisions -, the primary goal is inducing stakeholders to an erroneous perception of the firm's actual financial status. Strategies differ in terms of their impact on cash flow, among other aspects. Specifically, real operating activities consume resources and they divert firms from normal business practices.

The biased scenario created by RAM hides the negative consequences of firms' performance (Graham, Harvey, \& Rajgopal, 2005; Gunny, 2010; Roychowdhury, 2006), increases volatility of future cash flows (Ge, 2010), and reduces firm value (Xu, 2008). These consequences of using RAM may be illustrated by discussing some techniques employed to achieve manipulation.

A technique consists in offering discount on prices charged for goods to boost sales, which is focused on the short term and has the effect of increasing earnings for the current period. The outcome reported for the period increases and a positive profit margin remains after the discount. However, this kind of discount has an adverse effect on future earnings, since consumers are no longer willing to buy when price come back to their previous levels. According to Gunny (2010), this impact on future sales may lead to lower profit margins in subsequent periods.

Another method to boost sales is increasing credit, offering more flexible terms, such as longer settlement periods or less stringent guarantee requirements. Although this may improve sales during the current period, the practice also increases the risk of nonpayment (Ge, 2010) and it forces a review of cash flow management, since receipts are spread more thinly across a larger number of installments.

Alternatively, production may be increased in order to dilute fixed costs across a larger number of units, accumulating larger stocks of finished products to be sold during subsequent financial periods. However, if it is hard for the firm to sell this excessive production, i.e. if future demand is lower than the volume of products produced in previous periods, the cost to maintain stocks has a negative impact on the outcomes of the periods affected (Xu, 2008).

Regarding the effects of these techniques, Li (2010) argues that the relation between abnormal levels of operational activity and future firm performance is an empirical issue, since the various management techniques have different consequences for cash flow during the financial period. For instance, both cutting discretionary expenses and increasing production levels consist in techniques to adjust operations in order to achieve real operating activities management. However, whereas the first method increases cash flow during the period (assuming that discretionary expenses are paid in cash or cash equivalents), the second option reduces cash flow, assuming sale volumes are unchanged. Additionally, RAM does not always affect cash flow and profits in the same direction (Gunny, 2010). Although increasing production to reduce the cost of products may increase profits, it may reduce cash flow if the increase in sales is not enough to absorb the increase in unsold stocks.

Academic interest in the relation between RAM and profitability of shares is recent (Zang, 2012). Gunny (2010) published a pioneering study in the area, where four proxies for activities linked to manipulation through real operating activities were analyzed with data from 1988 to 2000 on U.S. firms. It was found that all proxies tested were associated with significantly lower performance both in terms of profitability of shares and future cash flow. Li (2010) confirmed the findings of Gunny (2010) by using an extended dataset from 1988 to 2008 and the study also showed that market's inefficiency to identify RAM and correct forecasts for share prices led to abnormal return of $6 \%$ per year for a hedging strategy. These findings contrast with evidence reported by Bhojraj, Hribar, Picconi and McInnis (2009), where the return per share was lower in years following periods with use of RAM.

\section{METHODOLOGY}

\subsection{Data and Sample Selection}

The sample comprised companies listed on the BM\&FBOVESPA for which financial and accounting data were made available by the Economatica ${ }^{\circledR}$. Accounting data were extracted from financial statements of individual companies.
Assets representing financial companies (insurance, banking, and investment funds) or companies operating in the energy or telecommunications sectors were excluded from the analysis, it is a common practice in studies like ours (Gunny, 2010; Badertscher, 2011). A reason for excluding such shares is the fact that these 
sectors are heavily regulated, there is proprietary legislation, and these specific standards have an idiosyncratic effect on accounting (Gunny, 2010). Companies classified by Economatica as "Other Sector" were also excluded, because they are not associated with sectors covered by this study.

Observations were collected on an annual basis for the period from 1989 to 2012. Although the Economatica ${ }^{\circ}$ provides data going back to 1986 , the small number of companies tracked between 1986 and 1988 means that excluding these 3 years does not lead to relevant loss of information. Furthermore, this procedure considerably reduced the number of extreme observations (outliers). Thus, 1989 was chosen as the initial year of analysis. In turn, 2012 was the final year of analysis because it was the last year for which data were available on the Economatica ${ }^{\circ}$ when the research was conducted.

To neutralize the effects arising from changes in the purchasing power of money, historical data was collected considering the adjustment for inflation. Specifically, historical data has been adjusted according to the Brazilian Broad National Consumer Price Index (IPCA), provided by the Brazilian Institute of Geogra- phy and Statistics (IBGE), converted to values for May 2013.

Sample size for identifying RAM refers to the number of observations in the data used for regressions to estimate the expected level of accruals and real operating activities (and, as a result, for residuals, which represent the level of earnings management).

\subsection{Models of Real Activities Management}

Identifying manipulation through real operating activities requires empirical application of models. These models estimate the "normal" level of operational activities, thus their regression residuals represent the "abnormal" level, i.e. they are proxies for management variables. In other words, the abnormal component of real operating activities consists in the difference between the actual value observed and the estimate obtained by applying the models (Gunny 2010; Roychowdhury, 2006).

The abnormal level of discretionary expenses was estimated by using a model derived from the seminal study by Dechow, Kothari and Watts (1998), and Roychowdhury (2006), formulated as follows:

$$
\operatorname{Disc}_{E_{t}} / A_{t-1}=\alpha_{0}+\alpha_{1}\left(1 / A_{t-1}\right)+\beta_{2}\left(S_{t} / A_{t-1}\right)+\varepsilon_{t} \quad 1
$$

where $\operatorname{Disc}_{E}$ represents discretionary expenses, $A$ is total assets, and $S$ is sale revenues. For the sake of simplicity, the subscript " $i$ " was suppressed hereafter.

Equation (1) resorts to specification with panel data, considering all shares and the entire sampling period. Additionally, Hausman test was employed to detect correlated random effects. The model defines discretionary expenses for the current period as a function of the current level of sales, so that the regression residual represents the magnitude of manipulation by cutting discretionary expenses $\left(R A M_{D E_{t}}\right)$.

The second proxy used to capture manipulation through real operating activities is abnormal production levels $\left(R A M_{P R O D_{t}}\right)$, proposed by Dechow, Kothari and Watts (1998) and applied by Roychowdhury (2006):

$$
\operatorname{Prod} t_{t} / A_{t-1}=\alpha_{0}+\alpha_{1}\left(1 / A_{t-1}\right)+\beta_{1}\left(S_{t} / A_{t-1}\right)+\beta_{2}\left(\Delta S_{t} / A_{t-1}\right)+\beta_{2}\left(\Delta S_{t-1} / A_{t-1}\right)+\varepsilon_{t}
$$

where Prod is the cost of production and $\Delta$ is the first difference operator.

Martinez and Cardoso (2009) stress that the functionality of this formulation allows it to be applied to any sector. In turn, Roychowdhury (2006) explains that including the intercept standardized by total assets allows the independent variable to be different from zero even when there are no sales for the period $t$ or $t-1$. Gunny (2010) explains that analysis according to production costs - rather than by cost of products sold or changes in inventory - is a relevant consideration to avoid the distorting influence of ABM. For instance, a manager's decision to delay writing off a stock of obsolete products, to reduce the cost of products sold, might be manifested as an abnormally low cost of products sold. As a result, if cost of products sold was used as the variable of analysis, the effect of ABM could be erroneously classified as the effect of RAM. In contrast, by using production costs - i.e. cost of products sold and difference in inventory -, the effect of accruals could not be confused with that of real operating activities, because the reduced cost of products sold might be compensated by an increased difference in inventory.

Abnormal cash flow levels were used to detect manipulation of sales, specified as those shown in studies such as Ge (2010):

$$
O C F_{t} / A_{t-1}=\alpha_{0}+\alpha_{1}\left(1 / A_{t-1}\right)+\beta_{1}\left(S_{t} / A_{t-1}\right)+\beta_{2}\left(\Delta S_{t} / A_{t-1}\right)+\varepsilon_{t}
$$


where $O C F$ is operational cash flow.

Just as in formulas (1) and (2), regressions were analyzed with panel data specification, by using Hausman test to detect correlated random effects. The equation specified in (3) defines the expected operational cash flow as a linear function of sale revenues and change in sale revenues.

Manipulation through real operating activities to increase earnings may cause one of, or a combination of, the following effects (Cohen, Dey, \& Lys, 2008): abnormally low operational cash flow; abnormally low discretionary expenses; and abnormally high production costs. For the purposes of illustration, variables representing abnormal operational cash flow and abnormal discretionary expenses were multiplied by -1 . As a result, high values for the proxies for abnormal cash flow $\left(R A M_{C F O}\right)$ and abnormal discretionary expenses $\left(R A M_{D E}\right)$ indicate greater degrees of RAM (Roychowdhury, 2006; Cohen, Dey, \& Lys, 2008; Cohen \& Zarowin, 2010; Zang, 2012). Abnormal production costs were not multiplied by -1 , because high values of $R A M_{P R O D}$ already indicate high degrees of manipulation by RAM.

These three measurements of earnings management were also combined into an aggregated metrics, in order to identify the overall effect of manipulation. This metrics is the variable RAM, which captures the total impact of manipulation through real operating activities. It comprises the sum of abnormal cash flows $\left(R A M_{O C F}\right)$, abnormal discretionary expenses $\left(R A M_{D E}\right)$, and abnormal production costs $\left(R A M_{P R O D}\right)$. Since all of these measurements are standardized by total assets for the preceding financial period, they may be summed and the outcomes compared across companies of different sizes. Thus, high values for the variable RAM suggest intense use of real operating activities to manipulate the outcomes for the financial period.

As explained by Cohen, Dey and Lys (2008), different measurements of manipulation have different impacts on the outcomes reported, thus concentration in a single metrics could dilute and mask individual effects. Therefore, where applicable, the outcomes of the tests conducted are shown both for each variable that capture the individual effects of manipulation through real operating activities $\left(R A M_{C F O}, R A M_{D E}\right.$ and $\left.R A M_{P R O D}\right)$ and for the combined metrics (RAM).

\subsection{Tests of the Hypothesis}

The research hypothesis predicts a negative relation between using RAM and future ROA. Gunny (2010) argues that it is not clear a priori whether there is a relation between using RAM and future firm performan- ce. In this study, two indicators were chosen to test for such a relation and their behavior was analyzed within the year when manipulation is practiced and during the three periods before and after manipulation. Two proxies for future returns were chosen: profitability of shares, in the form of adjusted ROA $\left(R O A_{A d j}\right)$, and adjusted operational cash flow $\left(O C F_{A d j}\right)$, both calculated as the difference from the median for that indicator for the same year and business sector of the security concerned.

In order to achieve a more detailed analysis, firms included in the sample were classified into subtypes in terms of whether they met benchmarks and the types of RAM employed. The classification used is based on parameters described by Gunny (2010) and it divides firms as follows:

- Beating: takes the value 1 if (a) earnings before interest and taxes (EBIT) standardized by total assets for the previous period are greater than 0.01 ; (b) change in earnings per share from $t-1$ to $t$ is greater than $\mathrm{R} \$ 0.10$; (c) percentage variation in EBIT from $t-1$ to $t$ is greater than $1 \%$. Otherwise, the value of this variable is 0 .

- Meeting: takes the value 1 if (a) EBIT standardized by total assets for the previous period ranges from 0 to 0.01 ; (b) change in earnings per share from $t-1$ to $t$ is greater than or equal to $\mathrm{R} \$ 0.00$ and lesser than $\mathrm{R} \$ 0.10$; (c) percentage variation in EBIT from $t-1$ to $t$ ranges from 0 to $1 \%$; (d) Beating is not equal to 1 . Otherwise, the value of this variable is 0 .

- Closing: takes the value 1 if (a) EBIT standardized by total assets for the previous period ranges from -0.01 to 0 ; (b) change in earnings per share from $t-1$ to $t$ is greater than or equal to $-\mathrm{R} \$ 0.10$ and lesser than $\mathrm{R} \$ 0.00$; (c) percentage variation in EBIT from $t$ - 1 to $t$ ranges from $-1 \%$ to 0 ; (d) Beating and Meeting are not equal to 1 . Otherwise, the value of this variable is 0 .

- Missing: takes the value 1 if (a) EBIT standardized by total assets for the previous period is lesser than -0.01 ; (b) change in earnings per share from $t-1$ to $t$ is lesser than - $\mathrm{R} \$ 0.10$; (c) percentage variation in EBIT from $t-1$ to $t$ is lesser than $-1 \%$ and 0 ; (d) Beating, Meeting, and Closing are not equal to 1 . Otherwise, the value of this variable is 0 .

This classification was adopted to analyze the effect of RAM both on $R O A_{A d j}$ and $O C F_{A d j}$. Gunny (2010) warned about the difficulties to interpret the values identified in this breakdown, due to the systematic variation assigned to current return, firm size, or growth opportunities. Thus, the following regression was estimated:

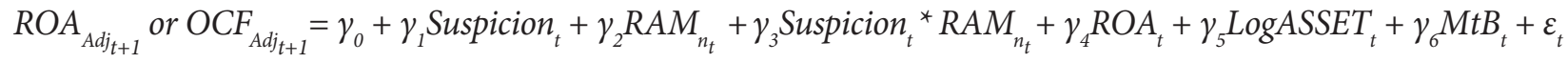

where $R O A_{A d j}\left(O C F_{A d j}\right)$ is adjusted ROA (cash flow), calculated as the difference in ROA (cash flow) of a speci- fic firm from the median for the same year and the same business sector of the one where the firm operates, Sus- 


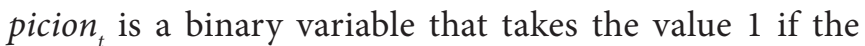
firm-year observation fits one of the benchmarks defined earlier in this section to indicate suspect firms, RAM $_{n}$ is RAM, where $n$ represents $D E$ (discretionary expen- ses), PROD (production costs) or OCF (operational cash flow), LogASSET is the natural logarithm of total assets, and $M t B$ is the market to book coefficient.

The next section describes the results.

\section{ANALYSIS OF RESULTS}

\subsection{Impact of RAM on Future Returns}

The hypothesis assumes there is a negative relation between using RAM and future firm returns. Panel A in Table 1 shows the results for ROA, adjusted by the median for corresponding year and firm business sector, covering the current period and the three years before and after the year under analysis. Panel B shows the results for cash flow, adjusted in a similar manner to $\mathrm{ROA}$, i.e. expressed as the difference in relation to the median for corresponding year and firm business sector. It is also worth highlighting that the indicators of returns (ROA \& cash flow) were "Winsorized" to a limit of $1.5 \%$ at the extremes of the distribution to reduce the effect of outliers.

Table 1 is divided into the different types of manipulation through RAM - $R A M_{D E_{t}}, R A M_{P R O D_{t}}$ and $R A M_{O C F_{t}}$. Additionally, firms are also classified into categories according to whether they met the criteria for the management benchmarks. Initially, the results are shown for returns according to adjusted ROA ( $\mathrm{Pa}-$ nel A) and then for returns according to adjusted cash flow (Panel B). In both panels, it was found that around $11 \%$ of the instances of management by reduction of discretionary expenses (435 observations), production costs (384 observations), and sales manipulation (341 observations) met one of the benchmarks.

Except for manipulation by $R A M_{\mathrm{OCF}_{t}}$, adjusted ROA for the year prior to management $(t-1)$ for firms meeting one of the benchmarks is lower than the mean for all firms in the sample ("All" row) than the mean for firms that beat ("Beating" row), marginally missed ("Closing" row) or significantly missed ("Missing" row) benchmarks. For instance, considering manipulation by cutting discretionary expenses $\left(R A M_{D E_{t}}\right)$, firms that met benchmarks had an adjusted ROA of $-8.26 \%$, compared to returns of $-4.71 \%$ for all firms and compared to $-3.83 \%,-6.86 \%$, and $-5.23 \%$ for firms classified as "Beating," "Closing," and "Missing," respectively.

Considering the percentage variation (data not shown in tables) in adjusted ROA at $t+1, t+2$, and $t+3$, firms classified as "Meeting" exhibited worse return than "All," "Beating," "Closing," and "Missing" firms, regardless of the type of manipulation by RAM employed. The rows labeled as $R A M_{D E_{t}}, R A M_{P R O D_{t}}$ and $\mathrm{RAM}_{\mathrm{OCF}_{t}}$ contain the results for firms in the last quintile of the distribution series for manipulation by cutting discretionary expenses, production costs, and sales manipulation, respectively. As such, the firms that mostly managed by cutting discretionary expenses had adjusted ROA of $-6.66 \%$ during the year of manipulation and $-8.14 \%,-9.56$, and $-11.31 \%$ at $t+1$, $t+2$ and $t+3$, respectively. Within this subset of firms, those that met benchmarks (Meeting ${ }^{*} R A M_{D E_{t}}$ ) exhibited an adjusted ROA even worse, with $-11.45 \% \mathrm{du}-$ ring the year of manipulation and $-14.77 \%,-16.53 \%$, and $-19.65 \%$ at $t+1, t+2$ and $t+3$, respectively. For firms that met benchmarks, but were not within the last quintile for manipulation by cutting discretionary expenses - Meeting (without $R A M_{D E_{t}}$ ) -, adjusted ROA was $-6.18 \%,-7.39 \%,-9.52 \%$, and $-9.29 \%$ at $t, t+1, t+2$ and $t+3$, respectively.

The results of analyses of other methods of manipulation through RAM - RAM ${ }_{\text {RROD }_{t}}$ and $R A M_{\mathrm{OCF}_{t}}$ - led to the same conclusions. Evidence suggests that, concerning ROA, firms that engage in RAM exhibit worse future returns than the average for their respective industrial sectors, as well as firms that do not manipulate their end of year outcomes.

Panel B in Table 1 displays the results of the analysis taking adjusted cash flow as the metrics for return. It shows that the adjusted cash flow of firms meeting the benchmarks drops over the three years following manipulation through RAM. Firms that are in the last quintile of the distribution for manipulation through RAM and also met benchmarks exhibited worse future cash flow than those in the other quintiles, during the first year after manipulation (in the case of $R A M_{D E_{t}}$ ) or the first two years after manipulation (in the case of $\left.R A M_{P R O D_{t}}\right)$. The same patterns were not observed for manipulation by sales $\left(R A M_{\mathrm{OCF}_{t}}\right)$, since firms that managed most (i.e. those in the last quintile) and met benchmarks exhibited a higher cash flow to other firms (i.e. to those in quintiles 1 to 4 ) that met benchmarks. This evidence confirms that firms that manage earnings by cutting discretionary expenses and by manipulating production costs have worse future cash flow than those that do not manipulate end of year outcomes. However, the same result was not observed when manipulation is achieved through $R A M_{O C F}$.

Gunny (2010) warned that univariate analyses such as those shown in Table 1 may suffer from bias, due 
to systematic variation of indicators of future returns (ROA and cash flow) with current return, firm size, and growth opportunities. Equation (4) was estimated for this reason.

Table 1 Returns (ROA and cash flow) by benchmarks and RAM categories

\begin{tabular}{|c|c|c|c|c|c|c|c|c|c|}
\hline & \multicolumn{9}{|c|}{ Mean } \\
\hline & N Obs. & Shares & $R O A_{A d j_{t-3}}$ & $R O A_{A d j_{t-2}}$ & $R O A_{A d j_{t-1}}$ & $R O A_{A d j_{t}}$ & $\boldsymbol{R O A}_{\text {Adj }_{t+1}}$ & $R O A_{A d j_{t+2}}$ & $\boldsymbol{R O A}_{\text {Adj }_{t+3}}$ \\
\hline \multicolumn{10}{|l|}{ Panel A - Adjusted ROA } \\
\hline \multicolumn{10}{|l|}{$\operatorname{RAM}_{D E_{t}}$} \\
\hline A/l & 4,058 & 891 & -0.0436 & -0.0455 & -0.0471 & -0.0501 & -0.0518 & -0.0556 & -0.0585 \\
\hline Beating & 3,806 & 951 & -0.0363 & -0.0372 & -0.0383 & -0.0371 & -0.0412 & -0.0456 & -0.0486 \\
\hline Meeting & 435 & 1,012 & -0.0742 & -0.0749 & -0.0826 & -0.0752 & -0.0923 & -0.1119 & -0.1167 \\
\hline Closing & 222 & 498 & -0.0617 & -0.0800 & -0.0686 & -0.0813 & -0.0909 & -0.0618 & -0.0802 \\
\hline Missing & 2,601 & 775 & -0.0530 & -0.0562 & -0.0523 & -0.0898 & -0.0794 & -0.0816 & -0.0852 \\
\hline$R A M_{D E_{t}}$ & 825 & 706 & -0.0784 & -0.0778 & -0.0752 & -0.0666 & -0.0814 & -0.0956 & -0.1131 \\
\hline Meeting $* R A M_{D E_{t}}$ & 114 & 1,167 & -0.1176 & -0.1108 & -0.1186 & -0.1145 & -0.1477 & -0.1653 & -0.1965 \\
\hline Meeting (without $R A M_{D E_{l}}$ ) & 321 & 995 & -0.0574 & -0.0620 & -0.0701 & -0.0618 & -0.0739 & -0.0952 & -0.0929 \\
\hline \multicolumn{10}{|l|}{ RAM $_{\text {PROD }_{t}}$} \\
\hline$A / /$ & 3,339 & 930 & -0.0429 & -0.0466 & -0.0499 & -0.0535 & -0.0567 & -0.0599 & -0.0643 \\
\hline Beating & 3,194 & 977 & -0.0357 & -0.0383 & -0.0412 & -0.0427 & -0.0465 & -0.0506 & -0.0547 \\
\hline Meeting & 384 & 1,008 & -0.0715 & -0.0778 & -0.0889 & -0.0844 & -0.1052 & -0.1284 & -0.1339 \\
\hline Closing & 185 & 455 & -0.0616 & -0.0802 & -0.0704 & -0.0842 & -0.0938 & -0.0613 & -0.0934 \\
\hline Missing & 2,139 & 800 & -0.0530 & -0.0584 & -0.0566 & -0.0950 & -0.0864 & -0.0881 & -0.0925 \\
\hline$R A M_{P_{R O D_{t}}}$ & 683 & 761 & -0.0560 & -0.0614 & -0.0789 & -0.0902 & -0.0872 & -0.0738 & -0.0748 \\
\hline Meeting * $R A M_{P R O D_{t}}$ & 77 & 920 & -0.1082 & -0.1204 & -0.1657 & -0.1577 & -0.1646 & -0.1667 & -0.1227 \\
\hline Meeting (without $R A M_{P R O D}$ ) & 307 & 1,034 & -0.0621 & -0.0667 & -0.0693 & -0.0656 & -0.0907 & -0.1196 & -0.1363 \\
\hline \multicolumn{10}{|l|}{$\operatorname{RAM}_{O C F_{t}}$} \\
\hline$A / l$ & 3,225 & 1,027 & -0.0215 & -0.0248 & -0.0272 & -0.0311 & -0.0377 & -0.0425 & -0.0453 \\
\hline Beating & 3,103 & 1,051 & -0.0188 & -0.0209 & -0.0231 & -0.0241 & -0.0311 & -0.0366 & -0.0392 \\
\hline Meeting & 341 & 1,174 & -0.0136 & -0.0172 & -0.0127 & -0.0149 & -0.0398 & -0.0484 & -0.0551 \\
\hline Closing & 160 & 564 & -0.0205 & -0.0390 & -0.0224 & -0.0409 & -0.0634 & -0.0424 & -0.0551 \\
\hline Missing & 2,066 & 920 & -0.0259 & -0.0311 & -0.0282 & -0.0634 & -0.0621 & -0.0639 & -0.0689 \\
\hline$R A M_{O C F_{t}}$ & 659 & 893 & -0.0272 & -0.0399 & -0.0527 & -0.0777 & -0.0698 & -0.0646 & -0.0718 \\
\hline Meeting ${ }^{*} R A M_{O C F_{t}}$ & 58 & 1,099 & -0.0243 & -0.0346 & -0.0459 & -0.0461 & -0.0542 & -0.0774 & -0.0976 \\
\hline \multirow[t]{2}{*}{ Meeting (without $R A M_{O F_{l}}$ ) } & 283 & 1,179 & -0.0115 & -0.0136 & -0.0060 & -0.0084 & -0.0367 & -0.0422 & -0.0461 \\
\hline & N Obs. & Shares & $O C F_{A d j_{t-3}}$ & $O C F_{A d j_{t-2}}$ & $O C F_{A d j_{t-1}}$ & $O C F_{A d j_{t}}$ & $O C F_{A d j_{t+1}}$ & $\mathrm{OCF}_{\mathrm{Adj}_{\mathrm{i}+2}}$ & $O C F_{A d j_{t+3}}$ \\
\hline \multicolumn{10}{|l|}{ Panel B - Adjusted cash flow } \\
\hline \multicolumn{10}{|l|}{$R_{A M_{D E_{t}}}$} \\
\hline$A / /$ & 4,058 & 891 & -0.0013 & -0.0028 & -0.0026 & -0.0019 & -0.0010 & 0.0002 & -0.0003 \\
\hline Beating & 3,806 & 951 & -0.0002 & -0.0018 & -0.0009 & 0.0020 & 0.0010 & 0.0011 & 0.0010 \\
\hline Meeting & 435 & 1,012 & 0.0030 & -0.0036 & 0.0078 & 0.0113 & 0.0057 & 0.0004 & 0.0050 \\
\hline Closing & 222 & 498 & -0.0162 & -0.0008 & -0.0072 & -0.0159 & -0.0131 & 0.0124 & -0.0051 \\
\hline Missing & 2,601 & 775 & -0.0042 & -0.0013 & -0.0030 & -0.0228 & -0.0106 & -0.0078 & -0.0068 \\
\hline$R A M_{D E_{t}}$ & 825 & 706 & -0.0051 & -0.0081 & -0.0078 & 0.0067 & 0.0010 & 0.0000 & -0.0070 \\
\hline Meeting $* R A M_{D E_{t}}$ & 114 & 1,167 & -0.0267 & -0.0250 & 0.0020 & 0.0129 & -0.0058 & 0.0051 & 0.0306 \\
\hline Meeting (without $R A M_{D E_{l}}$ ) & 321 & 995 & 0.0151 & 0.0041 & 0.0098 & 0.0108 & 0.0092 & -0.0010 & -0.0017 \\
\hline \multicolumn{10}{|l|}{$\operatorname{RAM}_{\text {PROD }_{t}}$} \\
\hline$A / /$ & 3,339 & 930 & -0.0015 & -0.0024 & -0.0017 & 0.0007 & -0.0000 & -0.0000 & -0.0009 \\
\hline Beating & 3,194 & 977 & -0.0003 & -0.0015 & -0.0001 & 0.0026 & 0.0009 & 0.0006 & -0.0005 \\
\hline Meeting & 384 & 1,008 & 0.0030 & -0.0036 & 0.0053 & 0.0142 & 0.0074 & -0.0015 & -0.0022 \\
\hline Closing & 185 & 455 & -0.0169 & -0.0006 & -0.0054 & -0.0142 & -0.0096 & 0.0135 & -0.0045 \\
\hline Missing & 2,139 & 800 & -0.0042 & -0.0011 & -0.0019 & -0.0214 & -0.0096 & -0.0087 & -0.0086 \\
\hline$R A M_{P_{R O D_{t}}}$ & 683 & 761 & -0.0002 & -0.0163 & -0.0169 & -0.0483 & -0.0136 & -0.0063 & 0.0022 \\
\hline Meeting $* R A M_{P R O D_{t}}$ & 77 & 920 & -0.0123 & -0.0329 & -0.0270 & -0.0307 & -0.0337 & -0.0292 & 0.0045 \\
\hline Meeting (without $R A M_{P R O D_{1}}$ ) & 307 & 1,034 & 0.0070 & 0.0039 & 0.0134 & 0.0245 & 0.0163 & 0.0049 & -0.0036 \\
\hline
\end{tabular}


Table 1

Cont.

\begin{tabular}{|c|c|c|c|c|c|c|c|c|c|}
\hline \multicolumn{10}{|l|}{$R A M_{\text {OCF }_{t}}$} \\
\hline$A / /$ & 3,225 & 1,027 & 0.0003 & 0.0000 & -0.0015 & -0.0008 & 0.0002 & -0.0001 & 0.0014 \\
\hline Beating & 3,103 & 1,051 & 0.0012 & 0.0009 & 0.0006 & 0.0014 & 0.0012 & 0.0004 & 0.0017 \\
\hline Meeting & 341 & 1,174 & 0.0099 & 0.0019 & 0.0124 & 0.0127 & 0.0101 & 0.0048 & 0.0029 \\
\hline Closing & 160 & 564 & -0.0135 & 0.0001 & -0.0106 & -0.0162 & -0.0126 & 0.0140 & -0.0022 \\
\hline Missing & 2,066 & 920 & -0.0014 & 0.0022 & -0.0016 & -0.0219 & -0.0097 & -0.0076 & -0.0050 \\
\hline$R A M_{O C F_{t}}$ & 659 & 893 & 0.0115 & 0.0086 & -0.0021 & -0.1229 & 0.0016 & 0.0032 & 0.0126 \\
\hline Meeting $* R A M_{O C F_{t}}$ & 58 & 1,099 & 0.0395 & 0.0045 & 0.0288 & -0.1115 & 0.0374 & 0.0187 & 0.0255 \\
\hline Meeting (without $R A M_{\mathrm{OCF}_{\mathrm{l}}}$ ) & 283 & 1,179 & 0.0038 & 0.0013 & 0.0089 & 0.0396 & 0.0040 & 0.0018 & -0.0021 \\
\hline
\end{tabular}

The sample comprises firm-year observations for 1989-2012. For each measurement of real activities management $\left(R A M_{D E_{1}} R A M_{P R O D_{t}}\right.$ and $\left.R A M O C F\right)$, firms were classified into the following categories:

- Beating: takes the value 1 if (a) EBIT standardized by total assets for the previous period is greater than 0.01 ; (b) change in Earnings per share from $t$ - 1 to $t$ is greater than R\$ 0.10; (c) percentage variation in EBIT from $t-1$ to $t$ is greater than $1 \%$. Otherwise, the value of this variable is 0 .

- Meeting: takes the value 1 if (a) EBIT standardized by total assets for the previous period ranges from 0 to 0.01 ; (b) change in Earnings per share from $t-1$ to $t$ is greater than or equal to $\mathrm{R} \$ 0.00$ and lesser than $\mathrm{R} \$ 0.10$; (c) percentage variation in EBIT from $t-1$ to $t$ ranges from 0 to $1 \%$; (d) Beating is not equal to 1 . Otherwise, the value of this variable is 0 .

- Closing: takes the value 1 if (a) EBIT standardized by total assets for the previous period ranges from - 0.01 to 0 ; (b) change in Earnings per share from $t$ - 1 to $t$ is greater than or equal to $-\mathrm{R} \$ 0.10$ and lesser than $\mathrm{R} \$ 0.00$; (c) percentage variation in EBIT from $t-1$ to $t$ ranges from $-1 \%$ to 0 ; (d) Beating and Meeting are not equal to 1 . Otherwise, the value of this variable is 0 .

- Missing: takes the value 1 if (a) EBIT standardized by total assets for the previous period is lesser than - 0.01 ; (b) change in Earnings per share from $t$ - 1 to $t$ is lesser than $-\mathrm{R} \$ 0.10$; (c) percentage variation in EBIT from $t-1$ to $t$ is lesser than $-1 \%$ and 0 ; (d) Beating, Meeting, and Closing are not equal to 1 . Otherwise, the value of this variable is 0 .

$R A M_{n_{t}}=$ takes the value 1 if $R A M_{n_{t}}$ (where $n$ may be DE [discretionary expenses], PROD [production costs], or OCF [operational cash flow]) falls within the last quintile. Otherwise, the value of this variable is 0 .

ROA_Adj is adjusted return on assets, calculated as the difference in ROA for a specific firm from the median for the same year and the same business sector as the one where the firm operates.

OCF_Adj is adjusted cash flow calculated as the difference in cash flow for a specific firm from the median for the same year and the same business sector as the one where the firm operates.

In turn, Table 2 shows the coefficients estimated by the regression of future returns against measurements of RAM. Panel A shows the results when adjusted ROA (difference in relation to the median for the respective business segment) was used as a metrics for return and Panel B shows the results of regression by using adjusted cash flow. Suspicion ${ }_{t}{ }^{*} R A M_{n_{t}}$ represents the inte- raction term for firms that met benchmarks and manipulated by using $R A M_{n_{t}}$, where $n$ may be $D E, P R O D$ or $O C F$. Since the purpose is testing for the overall effect of RAM, analyses were focused on the dependent variable $R A M_{t}$. Nevertheless, coefficients for manipulation broken down by the different types of RAM are also provided.

Table 2 Future returns against RAM

\begin{tabular}{|c|c|c|c|c|}
\hline \multicolumn{5}{|c|}{ Panel A - Adjusted ROA } \\
\hline & $R A M_{D E_{t}}$ & RAM $_{\text {PROD }_{t}}$ & $\boldsymbol{R A M}_{\text {OCF }_{t}}$ & $R_{A} M_{t}$ \\
\hline Intercept & -0.1260 & $-0.1430^{* * *}$ & $-0.1158^{* *}$ & $-0.1166^{* *}$ \\
\hline Suspicion $_{t}$ & -0.0090 & -0.0092 & $-0.0260^{* *}$ & $-0.0263^{* *}$ \\
\hline$R A M_{n_{t}}$ & -0.0670 & $-0.2087^{* * *}$ & -0.0447 & $-0.0585^{*}$ \\
\hline Suspicion $_{t} * R A M_{n_{t}}$ & $-0.4211^{* *}$ & -0.1560 & 0.0037 & -0.1051 \\
\hline$R O A_{t}$ & $0.3658^{* * *}$ & $0.3225^{* * *}$ & $0.3511^{* * *}$ & $0.3389^{* * *}$ \\
\hline $\log A S S E T_{t}$ & $0.0069^{*}$ & $0.0077^{* *}$ & $0.0073^{*}$ & $0.0071^{*}$ \\
\hline$M t B_{t}$ & $-0.0025^{* *}$ & $-0.0024^{* *}$ & $-0.0031^{* * *}$ & $-0.0032^{* * *}$ \\
\hline Obs. & 1,503 & 1,348 & 1,344 & 1,203 \\
\hline Adjusted $R^{2}$ & 0.64 & 0.67 & 0.54 & 0.56 \\
\hline \multicolumn{5}{|c|}{ Panel B - Adjusted cash flow } \\
\hline & $R A M_{D E_{t}}$ & $\operatorname{RAM}_{\text {PROD }_{t}}$ & $\boldsymbol{R A M}_{\mathrm{OCF}_{t}}$ & $R_{A} M_{t}$ \\
\hline Intercept & -0.0490 & -0.0778 & -0.0574 & -0.0561 \\
\hline Suspicion $_{t}$ & $-0.0170^{*}$ & -0.0083 & $-0.0146^{*}$ & -0.0109 \\
\hline$R A M_{n_{t}}$ & $0.1472^{*}$ & -0.0709 & $0.1040^{* * *}$ & $0.0480^{*}$ \\
\hline Suspicion $_{t} * R A M_{n_{t}}$ & -0.1278 & -0.1127 & 0.0709 & -0.0330 \\
\hline$R O A_{t}$ & $0.0545^{* *}$ & $0.0514^{*}$ & $0.1012^{* * *}$ & $0.0994^{* * *}$ \\
\hline $\log A S S E T_{t}$ & 0.0043 & 0.0063 & 0.0049 & 0.0047 \\
\hline$M t B_{t}$ & 0.0004 & 0.0003 & 0.0012 & 0.0012 \\
\hline
\end{tabular}


Cont.

\begin{tabular}{lcccc}
\hline Obs. & 1,269 & 1,138 & 1,184 & 1,059 \\
\hline Adjusted R & 0.14 & 0.18 & 0.14 & 0.17 \\
\hline
\end{tabular}

$*, * *$, and ${ }^{* * *}$ indicate that the difference observed between the first and fifth quintiles is different from zero with significance at $10 \%, 5 \%$, and $1 \%$, respectively. Coefficients were estimated for observations that comprised the sample from 1989 to 2012 by using panel data. Where applicable, the presence of unit roots was duly dealt with. The regression employed was as follows:

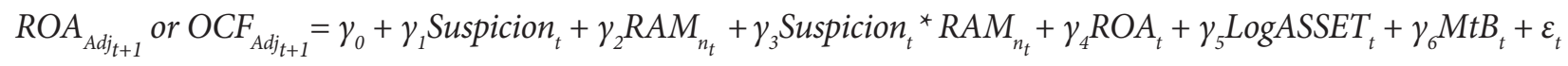

Panel A shows the results for analyses using adjusted ROA (difference from median for the firm's business sector) as a measurement for returns, while Panel B shows the results for analyses using adjusted cash flow. Suspicion ${ }_{t}^{*} R A M_{n_{t}}$ represents the combined effect when firms meet Benchmarks and manipulate by using $R A M_{n_{t^{\prime}}}$ where $\mathrm{n}$ may be $D E, P R O D$ or $O C F$.

The coefficients calculated for the variables Suspicion $\mathrm{e}_{t}$ $R A M_{n_{t}}$ shown in Panel A are negative and significant, demonstrating that firms that meet benchmarks and those that resort to RAM have negative returns at $t+1$. The combined effect of these variables (Suspicion ${ }_{t}{ }^{\star} R A M_{n_{t}}$ ) is not significant, indicating there is no marginal impact resulting from the interaction between these factors. In contrast, the coefficients in Panel B are not significant, except for a signi- ficant and positive relation between $R A M_{t}$ and cash flow at $t+1$. This result is intriguing and it goes against the initial assumptions, showing that RAM has a positive impact on firms' future cash flow. Taken together, this evidence partially confirms the hypothesis H1. Specifically, when the measurement of future returns is ROA, a negative relation with earnings management is detected, but the same is not true when the measurement for return is cash flow.

\section{CONCLUSIONS}

The hypothesis formulated and tested in this article predicted there would be a negative relation between the use of earnings management through real operating activities and firms' future returns. The measurements of future returns were ROA and cash flow. In the case of both measurements for return, the metrics analyzed was deviation from the respective median for the firm's business sector. Analyses covered returns during years before and after manipulation and during the year when RAM was used. Additionally, regressions were estimated for the measurements for return at $t+1$ with regard to the metrics for RAM, controlling the systematic effects of profitability, firm size, and growth opportunities. The results observed provide mixed evidence, partially supporting the hypothesis H1. Specifically, when the measurement for future returns is ROA, a negative relation with RAM is detected, but the same is not true when the measurement for returns is cash flow.

The results of this study are useful for stakeholders. First, the findings demonstrate the occurrence of manipulation through real operating activities in the Brazilian capital market, indicating that earnings management in Brazil goes beyond manipulation through accounting choices. Thus, users of financial statements should not only consider the effects of discretionary accruals, but also observe the effects of operational practices that affect end of year outcomes. This insight is relevant, because adjustments aimed at pricing in manipulation tend to be effective in proportion to awareness of the management techniques applied to disclose data.

Another significant contribution was demonstrating that there is a negative relation between use of earnings management through real operating activities and ROA. This finding is relevant for investors, particularly for the purposes of comparison and valuation of securities, since profitability is an indicator often used when deciding to provide funding and comparing returns between firms in the same sector, among other uses.

There is a fertile area of research in subjects related to RAM. This study did not examine a list of all potential RAM techniques, such as delaying or canceling new investment projects and hedging with derivatives. Additionally, factors such as institutional differences, the legal regime adopted (Code Law versus Common Law), corporate governance, the role of auditors, the influence of sophisticated investors, and the relevance of accounting information, some of which involve determinant costs of manipulation strategies, were not covered by this study. An extended analysis covering other forms of manipulation through real operating activities and additional determinant costs may increase understanding of the effects of this management strategy in the Brazilian capital market. 


\section{References}

Almeida-Santos, P. S. A. D., Verhagem, J. A., \& Bezerra, F. A. (2011). Gerenciamento de resultados por meio de decisões operacionais e a governança corporativa: análise das indústrias siderúrgicas e metalúrgicas brasileiras. Revista de Contabilidade e Organizações, 5(13), 55-74.

Badertscher, B. A. (2011). Overvaluation and the choice of alternative earnings management mechanisms. The Accounting Review, 86(5), 1491-1518.

Barton, J., \& Simko, P. J. (2002). The balance sheet as an earnings management constraint. The Accounting Review, 77(Supplement) $1-27$.

Bhojraj, S., Hribar, P., Picconi, M., \& McInnis, J. (2009). Making sense of cents: an examination of firms that marginally miss or beat analyst forecasts. The Journal of Finance, 64(5), 2361-2388.

Burgstahler, D., \& Dichev, I. (1997). Earnings management to avoid earnings decreases and losses. Journal of Accounting and Economics Properties of Accounting Earnings, 24(1), 99-126.

Cohen, D. A., Dey, A., \& Lys, T. Z. (2008). Real and accrual-based earnings management in the pre- and post-Sarbanes-Oxley periods. Accounting Review, 83(3), 757-787.

Cohen, D. A., \& Zarowin, P. (2010). Accrual-based and real earnings management activities around seasoned equity offerings. Journal of Accounting and Economics, 50(1), 2-19.

Cupertino, C. M. (2013). Gerenciamento de resultados por decisões operacionais no mercado de capitais brasileiro (Doctoral Thesis). Florianópolis, SC: Universidade Federal de Santa Catarina.

Dechow, P. M., Ge, W., \& Schrand, C. M. (2010). Understanding earnings quality: a review of proxies, their determinants and their consequences. Journal of Accounting and Economics, 50(2-3), 344-401.

Dechow, P. M., Kothari, S. P., \& Watts, R. L. (1998). The relation between earnings and cash flows. Journal of Accounting and Economics, 25(2), $133-168$.

Demski, J. S. (2004). Endogenous expectations. The Accounting Review, 79(2), 519-539.

Enomoto, M., Kimura, E, \& Yamaguchi, T. (2015, in press). Accrual-based and real earnings management: an international comparison for investor protection (Working Paper). Retrieved from http://dx.doi. org/10.2139/ssrn.2066797

Ewert, R., \& Wagenhofer, A. (2005). Economic effects of tightening accounting standards to restrict earnings management. Accounting Review, 80(4), 1101-1124.

Galdi; F. C. (2008). Estratégias de investimento em ações baseadas na análise de demonstrações contábeis: é possível prever o sucesso? (Doctoral Thesis). São Paulo, SP: Universidade de São Paulo.

$\mathrm{Ge}, \mathrm{W}$. (2010). Essays on real earnings management (Doctoral Thesis). Montreal, Canadá: McGill University.

Graham, J. R., Harvey, C. R., \& Rajgopal, S. (2005). The economic implications of corporate financial reporting. Journal of Accounting and Economics, 40(1-3), 3-73.

Gunny, A. K. (2010). The relation between earnings management using real activities manipulation and future performance: evidence from meeting earnings benchmarks. Contemporary Accounting Research, 27(3), 855-888.

Joosten, C. (2012). Real earnings management and accrual-based earnings management as substitutes (Master's Dissertation). Tilburg, Holanda: Tilburg University.

Kothari, S. P. (2001). Capital markets research in accounting. Journal of Accounting and Economics, 31(1-3), 105-231.

$\mathrm{Li}, \mathrm{X}$. (2010). Real earnings management and subsequent stock returns. Retrieved from http://dx.doi.org/10.2139/ssrn.1679832

Lopes, A. B., \& Walker, M. (2008). Firm-level incentives and the informativeness of accounting reports: an experiment in Brazil. Retrieved from http://dx.doi.org/10.2139/ssrn.1095781

Machado, D. G. (2012). Influência da política de remuneração dos executivos no nivel de gerenciamento de resultados em empresas industriais brasileiras, estadunidenses e inglesas (Doctoral Thesis) Blumenau, SC: Universidade Regional de Blumenau.

Martinez, A. L. (2013). Earnings management in Brazil: a survey of the literature. Brazilian Business Review, 10(4), 1-29.

Martinez, A. L., \& Cardoso, R. L. (2009). Gerenciamento de resultados contábeis no Brasil mediante decisões operacionais. Revista Eletrônica de Administracão, 15(3), 1-27.

Oswald, D. R., \& Zarowin, P. (2007). Capitalization of R\&D and the informativeness of stock prices. European Accounting Review, 16(4), 703-726.

Paulo, E. P. (2007). Manipulação das informações contábeis: uma análise teórica e empírica sobre os modelos operacionais de detecção de gerenciamento de resultados.(Doctoral Thesis). São Paulo, SP: Universidade de São Paulo.

Reis, E. M., Cunha, J. V. A., \& Ribeiro, D. M. (2014). Análise do gerenciamento de resultados por meio de decisões operacionais nas empresas componentes do IBrX - Índice Brasil. Advances in Scientific and Applied Accounting, 7(2), 201-223.

Rey, J. M. R. (2011). Gerenciamento de resultados baseado em escolhas contábeis e por decisões operacionais: estudo do impacto da Lei Sarbanes-Oxley em empresas brasileiras emissoras de ADRs (Master's Dissertation). Vitória, ES: Fucape Business School.

Roychowdhury, S. (2006). Earnings management through real activities manipulation. Journal of Accounting and Economics, 42(3), 335-370.

Santos, A., \& Paulo, E. (2006). Diferimento das perdas cambiais como instrumento de gerenciamento de resultados. Brazilian Business Review, 3(1), p. 15-31

$\mathrm{Xu}, \mathrm{Z}$. (2008). Three essays on real earnings management (Doctoral Thesis). Tuscaloosa, AL: The University: of Alabama.

Zang, A. (2012). Evidence on the tradeoff between real manipulation and accrual manipulation. The Accounting Review, (2), 675-703.

\section{Correspondence Address:}

\section{César Medeiros Cupertino}

Universidade Federal de Santa Catarina, Campus Reitor João David Ferreira Lima, Departamento de Ciências Contábeis Rua Engenheiro Agronômico Andrei Cristian Ferreira, s/n - CEP: 88040-900

Trindade - Florianópolis - SC - Brazil

Email: cupertino.cesar@ufsc.br 